\title{
Specific Polymerase Chain Reaction Identification of Venturia nashicola Using Internally Transcribed Spacer Region in the Ribosomal DNA
}

\author{
Bruno Le Cam, Martine Devaux, and Luciana Parisi
}

UMR de Pathologie Végétale, Institut National de la Recherche Agronomique, B.P. 57-42, rue Georges Morel, 49071 BEAUCOUZE Cedex, France.

Accepted for publication 31 May 2001.

\begin{abstract}
Le Cam, B., Devaux, M., and Parisi, L. 2001. Specific polymerase chain reaction identification of Venturia nashicola using internally transcribed spacer region in the ribosomal DNA. Phytopathology 91:900-904.

A technique based on the polymerase chain reaction (PCR) was developed for the identification of Venturia nashicola using nucleotide sequence information of the ribosomal DNA region. The complete internal transcribed spacer (ITS) region of $V$. nashicola strains and phylogenetically related species was amplified with the two universal ITS1 and ITS4 primers, sequenced, and digested with five restriction enzymes.

indicated constant polymorphisms between $V$. nashicola and related species at nucleotides 126 and 127, which overlapped a TaqI restriction site. An oligonucleotide primer named A126 was designed for identifying this variable region. A primer set (A126 and ITS4) that allowed the amplification of a 391-bp DNA fragment within the ITS region by PCR was specific to $V$. nashicola when it was checked against fungal genomic DNAs of related fungi. This primer set was a good candidate for a species-specific reagent in a procedure for identification of $V$. nashicola by PCR.
\end{abstract} The alignment of nucleotide sequences and analyses of digestion patterns
Additional keywords: Japanese pear, pear scab, Pyrus, V. pirina.
The fungus Venturia nashicola Tanaka and Yamamoto is the causal agent of scab on Japanese pear (Pyrus pyrifolia var. culta) and Chinese pear (Pyrus ussuriensis) and one of the most important diseases of Asian pears. Reliance is placed on fungicide use to control this serious disease because of the lack of scab-resistant commercial cultivars. Development of fungicide resistant strains has prompted plant pathologists and breeders to evaluate scab resistance in pear species and cultivars. Evidence that a source of resistance carried by cv. Kinchaku that could be used in breeding programs has been reported $(8,9)$. Within strains isolated from Japanese pear, existence of three physiological races of $V$. nashicola on Japanese pear was demonstrated (9), and all these races were avirulent on cv. Kinchaku.

Pyrus pyrifolia var. culta is poorly cultivated in Europe where host Pyrus communis (European pear) is predominant. A distinction between oriental and occidental pears was clearly established by molecular data based on restriction fragment length polymorphism (RFLP) banding pattern obtained from chloroplast DNA (6). Scab that occurred on European pear is caused by $V$. pirina, which causes severe losses in some places.

Based on nucleotide sequence of rDNA, V. nashicola is very close to $V$. pirina and both are genetically distinct from the Venturia spp. found on other fruit trees (14). Morphological differences and physiological specialization were reported between these two species by different authors $(7,15,18,19)$. However, their distinction based on morphological characteristics remains difficult (17). In 1999, Schnabel et al. (14) considered that the question of whether $V$. nashicola could be a race of $V$. pirina rather than a distinct species was still open. More recently, Ishii and Yanase (10) reexamined the relationship between these two putative fungal species and concluded that $V$. nashicola was a species

Corresponding author: B. Le Cam; E-mail address: lecam@angers.inra.fr

Publication no. P-2001-0717-01R

(C) 2001 The American Phytopathological Society distinct from $V$. pirina. Their results based on pathogenicity tests and mating experiments, clearly demonstrated the existence of host specificity and sexual barrier.

$V$. nashicola is a quarantine organism in Europe. To date, no sensitive detection technique is available. Morphological differentiation between these two species based on conidia and ascospores size is possible (10) but not sufficient to make a clear identification in practice. Moreover, it needs, in any case, to cultivate and store reference strains that pose a biohazard risk in countries in which $V$. nashicola is a quarantine pathogen. To date, there is a lack of workable molecular data within this genus (14), but because it is now demonstrated that these two scab agents belong to two distinct species, we may hypothesis that DNA workable differences exist. In this context, a molecular approach seemed capable to distinguish them. Analysis of DNA sequences has brought significant advances in identification of species in general. Several approaches may be used. Most of them are based on nondefined target DNA sequences, which include analysis of RFLP and analysis of random amplified polymorphic DNAs that have been in use for a decade $(22,24)$, and more recent techniques such as amplified fragment length polymorphism (20) and direct amplification of length polymorphism (1). Because of their ancestral trait, rDNA sequences have been commonly used in phylogenetic studies and, therefore, as targets to differentiate species by polymerase chain reaction (PCR)-based methods. Analysis of internal transcribed spacer (ITS) nucleotide sequences has solved classification problems at the intra-generic level for many phytopathogenic fungi such as Pythium spp. (21) or Colletotrichum spp. $(3,16)$ and enables fungal detection based on species-specific and even race-specific PCR methods (2,5).

The aim of this study was to develop a PCR-specific assay for the identification of $V$. nashicola. A combination of PCR and RFLP analyses was carried out to characterize ITS regions of 25 isolates of $V$. nashicola and V. pirina. Nucleotide sequences of two strains representing each species were aligned in order to design specific primers, and experimental PCR conditions were defined to allow identification of $V$. nashicola. 


\section{MATERIALS AND METHODS}

Fungal strains. Strains of V. nashicola and V. pirina used in this study are listed in Table 1 and their characteristics and provenance are detailed. Strains of related Venturia spp. (anamorph Spilocaea) used to validate specificity of PCR primers were collected from fruit trees and ornamental hosts as listed in Table 1. Strains were stored continuously at $4^{\circ} \mathrm{C}$ on malt agar medium in the laboratory.

DNA isolation. A quick method was developed to obtain DNA from Venturia cultures suitable for use in PCR. Plugs of mycelium from a 3-week-old culture were placed on an autoclaved cellophane sheet first deposited on the surface of a malt agar (Merck, Darmstadt, Germany) petri dish. Ten milligrams of mycelium was collected with a scraper after 7 days of incubation at $17^{\circ} \mathrm{C}$. DNA extraction was derived from the technique described by Goodwin and Lee (4). Each sample was placed in a $1.5-\mathrm{ml}$ microcentrifuge tube containing $100 \mu \mathrm{l}$ of lysis buffer $(50 \mathrm{mM}$ Tris- $\mathrm{HCl}$ at $\mathrm{pH} 7.2$, $50 \mathrm{mM}$ EDTA, 3\% sodium dodecyl sulfate, and 1\% 2-mercaptoethanol) heated at $80^{\circ} \mathrm{C}$. Tubes were then placed in a microwave oven. Samples were treated with three successive sequences $(15 \mathrm{~s}$, $10 \mathrm{~s}, 5 \mathrm{~s}$ ) at $750 \mathrm{~W}$. Three hundred microliters of lysis buffer was added to each tube. Tubes were incubated at $80^{\circ} \mathrm{C}$ for $10 \mathrm{~min}$, extracted once with $400 \mu \mathrm{l}$ of phenol/chloroform/isoamyl alcohol (25:24:1), and centrifuged at $14,000 \times g$ for $15 \mathrm{~min}$. The supernatant was transferred to a new microtube, and DNAs were precipitated in 1 volume of cold isopropanol with $10 \mu \mathrm{l}$ of $5 \mathrm{M}$ potassium acetate and centrifuged at $14,000 \times g$ for $4 \mathrm{~min}$. Pellets were washed with $200 \mu \mathrm{l}$ of $70 \%$ ethanol, air dried, resuspended in $50 \mu \mathrm{l}$ of distilled water, and stored at $-20^{\circ} \mathrm{C}$

ITS rDNA amplification. ITS1-5.8S-ITS2 rDNA was amplified by PCR. The primer sequences were 5'-TCCGTAGGTGAACCTGCGG-3' (ITS1) from the 18S and 5'-TCCTCCGCTTATTGATATGC-3' (ITS4) from the 28S rDNA (23). PCR was performed

TABLE 1. Fungal strains used and analysed for primer specificity ${ }^{\mathrm{a}}$

\begin{tabular}{|c|c|c|c|}
\hline Fungal strain & $\begin{array}{l}\text { Isolation or reference } \\
\text { (country and date) }\end{array}$ & Host plant & $\begin{array}{l}\text { Polymerase chain reaction } \\
\text { amplification with primers } \\
\text { A126/ITS } 4\end{array}$ \\
\hline \multicolumn{4}{|l|}{ Venturia pirina } \\
\hline $\mathrm{P} 1$ & Haute Savoie, France - 1988 & Pyrus communis cv. Conférence & - \\
\hline $\mathrm{P} 11^{\mathrm{b}}$ & Beaucouze, France - 1991 & Pyrus communis cv. Président Drouart & - \\
\hline P13 & Sarthe, France - 1986 & Pyrus communis cv. Pierre Corneille & - \\
\hline $\mathrm{P} 20$ & Beaucouze, France - 1987 & Pyrus communis cv. Duchesse de Mouchy & - \\
\hline $\mathrm{P} 30$ & Haute Savoie, France - 1987 & Pyrus communis cv.Conférence & - \\
\hline P52 & Beaucouze, France - 1992 & Pyrus communis cv.Williams & - \\
\hline P55 & Beaucouze, France - 1992 & Pyrus communis cv.Williams & - \\
\hline $\mathrm{P} 22$ & Beaucouze, France - 1987 & Pyrus communis cv.Louise Bonne & - \\
\hline $\mathrm{P} 64^{\mathrm{b}}$ & The Netherlands - 1995 & Pyrus communis cv. Doyenne & - \\
\hline $\mathrm{Vp} 1^{\mathrm{c}}$ & Dossenheim, Germany - 1995 & Pyrus communis cv. Vereinsdechant & - \\
\hline $\mathrm{Vp} 2^{\mathrm{c}}$ & Dossenheim, Germany - 1995 & Pyrus communis cv. Gute Luise & - \\
\hline $\mathrm{Vp} 3^{\mathrm{c}}$ & Braunschweig, Germany - 1999 & Pyrus communis & - \\
\hline $\mathrm{Vp} 4^{\mathrm{c}}$ & Dossenheim, Germany -1999 & Pyrus communis cv. Williams Christ & - \\
\hline \multicolumn{4}{|l|}{ Venturia nashicola } \\
\hline P6 & Balma, France - 1988 & Pyrus pyrifolia var. culta & + \\
\hline P8 & Balma, France - 1988 & Pyrus pyrifolia var. culta & + \\
\hline $\mathrm{P} 17^{\mathrm{b}}$ & Lanxade, France - 1991 & Pyrus pyrifolia var. culta & + \\
\hline P49 & Lanxade, France - 1991 & Pyrus pyrifolia var. culta & + \\
\hline P57 & Clermont Ferrand, France - 1993 & Pyrus pyrifolia var. culta & + \\
\hline P60 & Clermont Ferrand, France - 1993 & Pyrus pyrifolia var. culta & + \\
\hline P63 ${ }^{\mathrm{b}}$ & Bergerac, France - 1996 & Pyrus pyrifolia var. culta & + \\
\hline Mamenashi $12 \mathrm{~A} 1-3^{\mathrm{d}, \mathrm{e}}$ race 2 & Tottori, Japan - 1991 & Wild pear strain Mamenashi 12 & + \\
\hline Mamenashi $12 \mathrm{~B} 1-1^{\mathrm{e}}$ race 3 & Tottori, Japan - 1991 & Wild pear strain Mamenashi 12 & + \\
\hline Mamenashi $12 \mathrm{~B} 1-2^{\mathrm{e}}$ race 3 & Tottori, Japan - 1991 & Wild pear strain Mamenashi 12 & + \\
\hline JS $115^{\mathrm{e}}$ race 1 & Oita, Japan - 1980 & Pyrus pyrifolia var. culta cv. Hakko & + \\
\hline Yasato $2-1-1^{\mathrm{e}}$ race 1 & Ibaraki, Japan - 1992 & Pyrus pyrifolia var. culta cv. Kosui & + \\
\hline \multicolumn{4}{|l|}{ Spilocaea eriobotryae } \\
\hline $1389^{f}$ & Montpellier, France - 1998 & Eriobotrya japonica (loquat) & - \\
\hline \multicolumn{4}{|l|}{ Venturia inaequalis } \\
\hline 301 race 1 & Ahrensburg, Germany - 1988 & Malus $\times$ domestica $81 / 19-53 \mathrm{~g}$ & - \\
\hline $302^{\mathrm{b}}$ race 6 & Ahrensburg, Germany - 1988 & Malus $\times$ domestica $81 / 11-22^{\mathrm{h}}$ & - \\
\hline $\mathrm{V} 82^{\mathrm{c}}$ & Colombia - 1997 & Malus $\times$ domestica $\mathrm{cv}$. Golden dorsett & - \\
\hline $\mathrm{V} 71^{\mathrm{c}}$ & Turkey - 1996 & Malus $\times$ domestica & - \\
\hline $1066^{i}$ race 7 & Beaucouze, France - 1993 & Malus floribunda 821 & - \\
\hline \multicolumn{4}{|l|}{ Spilocaea pyracanthae } \\
\hline 186 & Ireland - 1987 & Pyracantha sp. & - \\
\hline 38.2 & Beaucouze, France - 1993 & Pyracantha sp. & - \\
\hline 38.7 & Beaucouze, France - 1993 & Pyracantha sp. & - \\
\hline $\mathrm{V} 56^{\mathrm{c}}$ & Dossenheim, Germany - 1995 & Pyracantha sp. & - \\
\hline $\mathrm{V} 55^{\mathrm{c}}$ & Dossenheim, Germany - 1995 & Pyracantha sp. & - \\
\hline
\end{tabular}

a Unless otherwise specified, the strains were from our laboratory.

b Strains in which internal transcribed spacer (ITS) region was sequenced.

c Strains were supplied by A. Kollar, Institute for Plant Protection in Fruit Crops, Dossenheim, Germany.

d ITS sequence of strain was published by Schnabel et al. (14) (GenBank Accession No. AF065846) and was aligned in Figure 2.

e Strains were supplied by H. Ishii, National Institute of Agro-Environmental Sciences, Ibaraki, Japan.

${ }^{f}$ Strain 1389 was supplied by J. L. Notteghem, ENSA Montpellier, France.

g Progeny $(v f / v f)$ of a Prima $(V f / v f) \times \mathrm{KI} 40(v f / v f)$ cross.

h Progeny $(V f / v f)$ of a Prima $(V f / v f) \times$ A143/24 $(v f / v f)$ cross.

i Strain originating from the Fl 1 isolate described by Roberts and Crute (13). 
in a $0.2-\mathrm{ml}$ tube with a total volume of $50-\mu 1$ reaction mixture containing $0.8 \mu \mathrm{M}$ forward and reverse primer, $200 \mu \mathrm{M}$ each dNTP, 1 unit of red Gold Star polymerase (Eurogentec SA, Herstal, Belgium), and $30 \mathrm{ng}$ of genomic DNA in a $1 \times$ amplification buffer $(75 \mathrm{mM}$ Tris- $\mathrm{HCl}$ buffer at $\mathrm{pH} 9$ supplemented with $20 \mathrm{mM}\left(\mathrm{NH}_{4}\right)_{2} \mathrm{SO}_{4}, 0.01 \%$ (wt/vol) Tween 20, and $5 \mathrm{mM} \mathrm{MgCl} 2$ ). PCR was carried out in a thermocycler (GeneAmp PCR System 9700; Applied Biosystems Inc., Foster City, CA) programmed for 30 cycles consisting of a denaturing step at $94^{\circ} \mathrm{C}$ for $30 \mathrm{~s}$, an annealing step at $60^{\circ} \mathrm{C}$ for $30 \mathrm{~s}$, and an extension step at $72^{\circ} \mathrm{C}$ for $45 \mathrm{~s}$. These cycles were preceded by an initial denaturation step at $94^{\circ} \mathrm{C}$ for $5 \mathrm{~min}$ and ended with a final extension at $72^{\circ} \mathrm{C}$ for $7 \mathrm{~min}$. The PCR products were analyzed by electrophoresis through $1.4 \%$ agarose gel in a $0.5 \times$ Tris-borate-EDTA buffer, stained with ethidium bromide, and visualized under UV light (300 nm).

DNA sequencing. ITS regions were sequenced for two strains of each species. PCR products were purified by a Qiagen Kit (Qiagen, Hilden, Germany) and sequenced automatically by an ABI 377 DNA sequencer with a Taq Dye Deoxy terminator sequencing kit (Applied Biosystems). Primers ITS1 and ITS4 were used for sequencing reactions.

Restriction of amplified products. To assess sequence variability within and between species, amplified ITS products of $V$. nashicola and $V$. pirina isolates were digested with restriction endonucleases TaqI, EcoRI, MspI, Tsp509I (Eurogentec), and RsaI (New England Biolabs Inc., Beverly, MA). Reactions were carried out following the manufacturer's recommendations. Digestions were performed in a final volume of $20 \mu \mathrm{l}$ with 12 or $15 \mu \mathrm{l}$ of PCR products and 8 units of enzymes. Restriction fragments were separated on $3.2 \%$ Nusieve GTG agarose gels (FMC BioProducts, Rockland, ME) and visualized as previously described. A 100-bp molecular weight ladder (Eurogentec) was used as size standard.

Primer design and PCR conditions for specific identification of $\boldsymbol{V}$. nashicola. In addition to DNA sequences obtained in this study, data on ITS1-5.8S-ITS2 sequences from other strains belonging to Venturia spp. were obtained from GenBank. It included data from two Japanese strains of $V$. nashicola (Mamenashi 12A1-1 and Mamenashi 12A1-3) and from four strains of V. pirina (MPS8
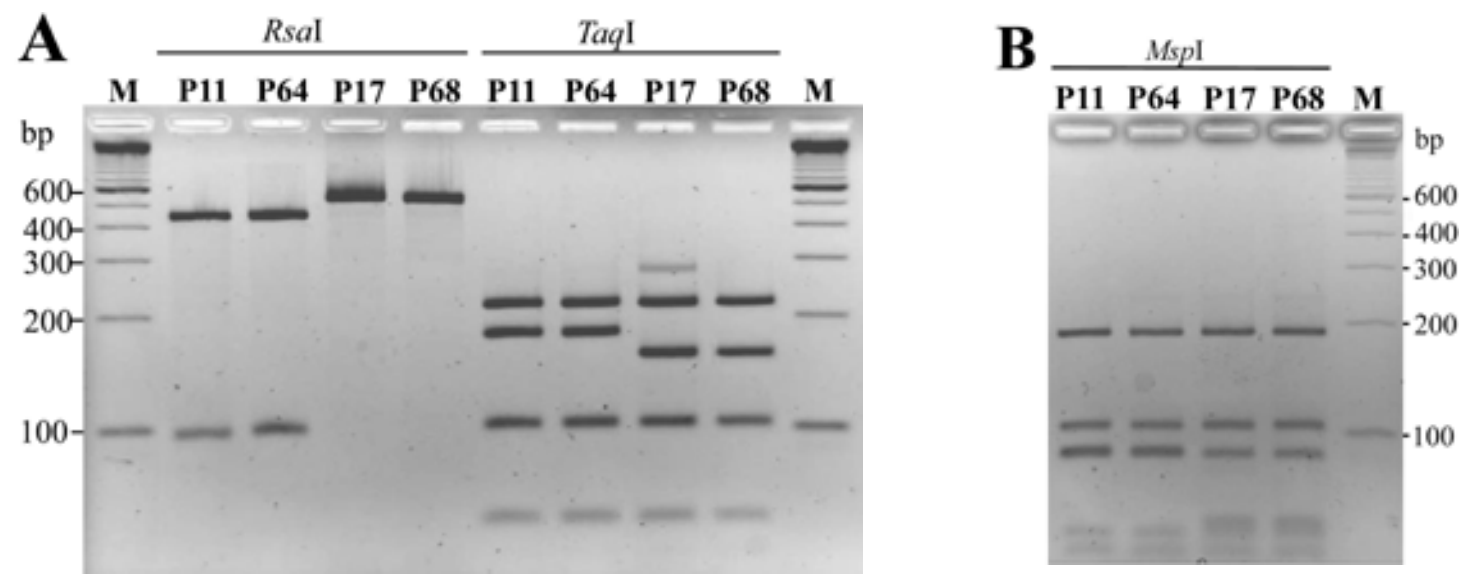

Fig. 1. Enzyme restriction digests of ribosomal DNA amplified with universal primers (internal transcribed spacer 1 [ITS1] and ITS4) from Venturia pirina (strains P11 and P64) and V. nashicola (strains P17 and P68) using A, RsaI and TaqI, and B, MspI. Lane M, 100-bp ladder.

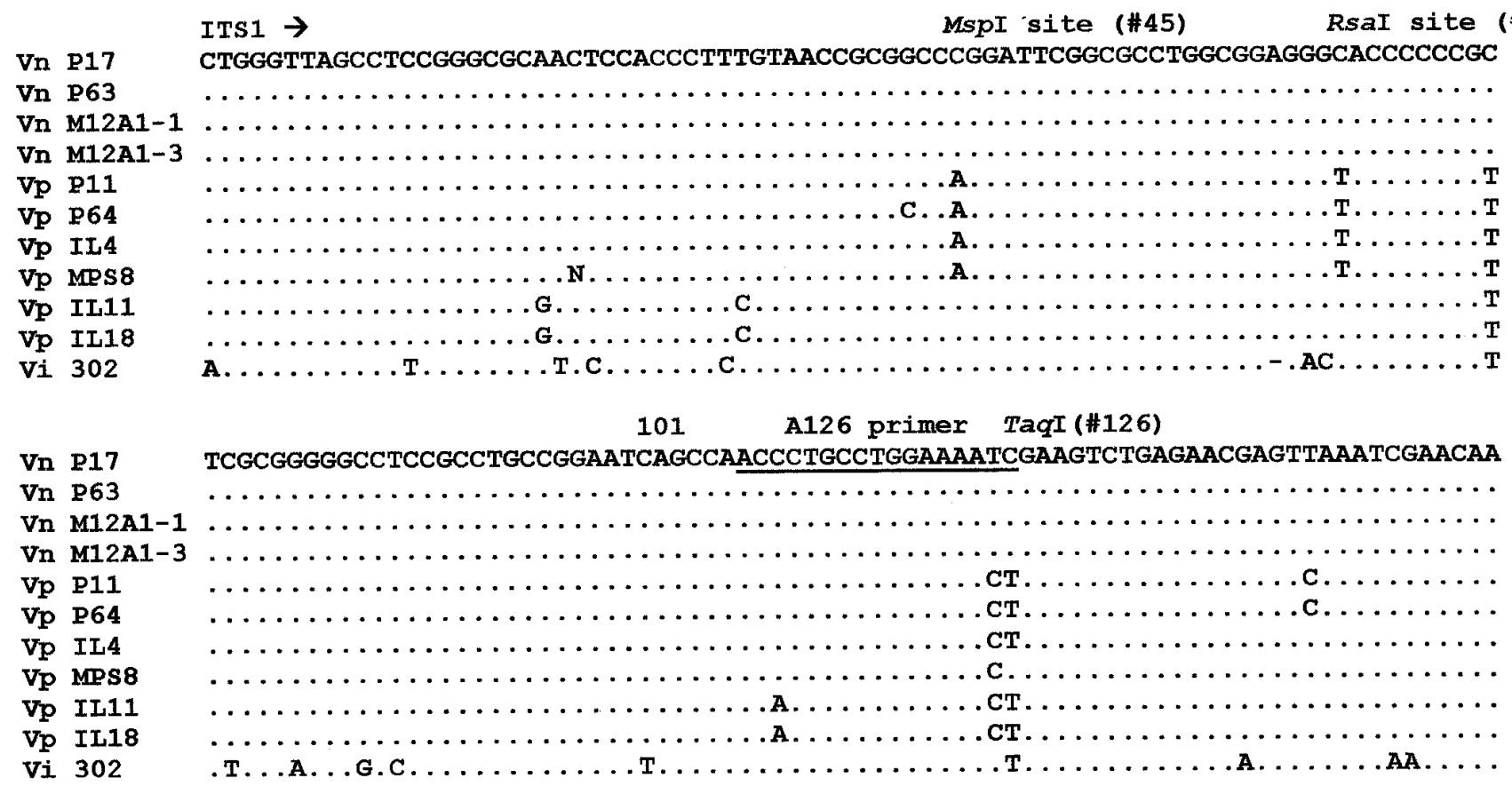

Fig. 2. Alignment of the complete internal transcribed spacer 1 (ITS1) nucleotide sequences (5' to $3^{\prime}$ ) for Venturia nashicola (Vn) strains P17, P63, M12A1-1, and M12A1-3; V. pirina (Vp) strains P11, P64, IL4, MPS8, IL11, and IL18; and V. inaequalis (Vi) strain 302. Underlined nucleotides identify the internal forward primer (A126) used to amplify specifically DNA from V. nashicola strains. 
from the United States and IL4, IL11, and IL18 from Israel); their accession numbers are AF065845, AF065846, AF065840, and AF065842 to AF065844, respectively (14). All these sequences were aligned. Differences in nucleotides between these sequences and data obtained by PCR/RFLP were used to design PCR primers putatively specific to $V$. nashicola. PCR conditions used to specifically amplify $V$. nashicola were the same as those described previously.

\section{RESULTS}

ITS products PCR. A single amplification product of 501 to $502 \mathrm{bp}$ was obtained for tested DNA samples originating from all of the strains listed in Table 1 that corresponded to the entire length of the ITS region (ITS1, 5.8S ribosomal gene, ITS2), plus a small portion of the small and large subunits of rRNA genes. Data obtained with nucleotide sequencing limited to ITS1, 5.8S, and ITS2 region showed polymorphism in length of amplicons, ranging from $461 \mathrm{bp}$ (V. nashicola) to $462 \mathrm{bp}$ (V. pirina). Analysis of additional sequences published by Schnabel et al. (14) confirmed this difference of at least one base between these two species.

PCR-RFLP on ITS region. Two enzymes of the five tested did not produce any polymorphism between species: the six-base restriction enzyme EcoRI cut DNA amplicons at one site and the four-base restriction enzyme $T s p 509$ I had two restriction sites. $R s a \mathrm{I}, T a q \mathrm{I}$, and $M s p \mathrm{I}$ enzymes provided different patterns between the two species (Fig. 1). The four-base restriction enzyme RsaI had one restriction site in the ITS region of $V$. pirina but none in that of $V$. nashicola. Analysis of TaqI restriction patterns indicated the occurrence of four sites in both species but differences in band size were observed. Five $M s p$ I sites were observed in the ITS region of $V$. pirina and six MspI sites in that of $V$. nashicola. No polymorphism was observed within each fungal species using these five restriction enzymes, except one strain of V. pirina $(\mathrm{Vp} 3)$ that had three sites for the restriction with RsaI instead of two.

DNA sequencing. Sequencing of ITS regions of two strains of each species was carried out to confirm the lack or the presence of restriction sites revealed by RFLP. Sequence alignment of additional strains of $V$. nashicola and $V$. pirina with diverse geographical origins displayed some mutations within species. Therefore, RsaI restriction site 69, which distinguished $V$. nashicola from $V$. pirina strains according to RFLP data, appeared variable. At this restriction site, no difference was observed between two $V$. pirina strains originating from Israel (IL11 and IL18) and all $V$. nashicola strains. Moreover, these two V. pirina strains and strains of $V$. nashicola had an MspI restriction site at nucleotide 45, whereas other strains of $V$. pirina did not. Alignment of all sequences confirmed a polymorphic region (nucleotides 126 and 127) between $V$. nashicola and V. pirina (Fig. 2). This region overlapped a TaqI site and corresponded to one or two nucleotides that mismatched, depending on $V$. pirina strains.

A primer, named A126, was designed, including the mismatches at the $3^{\prime}$ end (5'-ACCCTGCCTGGAAAATC-3'), to amplify only the strains of $V$. nashicola, whereas the second primer was the "universal" ITS4 oligonucleotide. The expected size of the PCR product was $391 \mathrm{bp}$. Three other regions specific to $V$. nashicola were pointed out: two transition mismatches at nucleotides 78 (Fig. 2) and 327, and a deletion of one base at nucleotide 451 observed in all $V$. nashicola (data not shown). No primer was designed in these regions because the differences were too slight and there was a lack of data on variability of these mismatches in other strains (Table 1).

Conditions for specific amplification. Validity of primer specificity was tested with genomic DNA extracted from all strains listed in Table 1. Standard conditions described for PCR of ITS region was not modified for this specific amplification, except annealing temperature was increased to $62^{\circ} \mathrm{C}$. All V. nashicola strains provided a single 391-bp amplicon. DNA extracted from $V$. inaequalis, Spilocaea pyracanthae, and S. eriobotryae do not amplify using these primers (Fig. 3); ITS rDNA amplification of these strains constituted a positive control.

\section{DISCUSSION}

The aim of this study was to characterize the ITS region of $V$. nashicola in order to provide tools for identification of strains belonging to this species. Our first approach, a restriction study carried out on ITS region, clearly identified three enzymes (TaqI, $R s a \mathrm{I}$, and $M s p \mathrm{I}$ ) that enabled differentiation of $V$. nashicola from $V$. pirina. Very low intraspecific polymorphism was detected with these enzymes.

Sequence data on these strains confirmed the mismatches between the two species. Alignment of additional sequences available in databanks indicated that at least one mutation at nucleotide 126 or 127, which overlapped a TaqI restriction site, was always present in $V$. nashicola strains. On the other hand, sequence alignment showed that other mutation points previously visualized by RFLP using RsaI and MspI enzymes presented intraspecific polymorphism and could not be considered good candidate sites to distinguish Venturia spp. The PCR primers we designed with these data were successfully used to identify $V$. nashicola

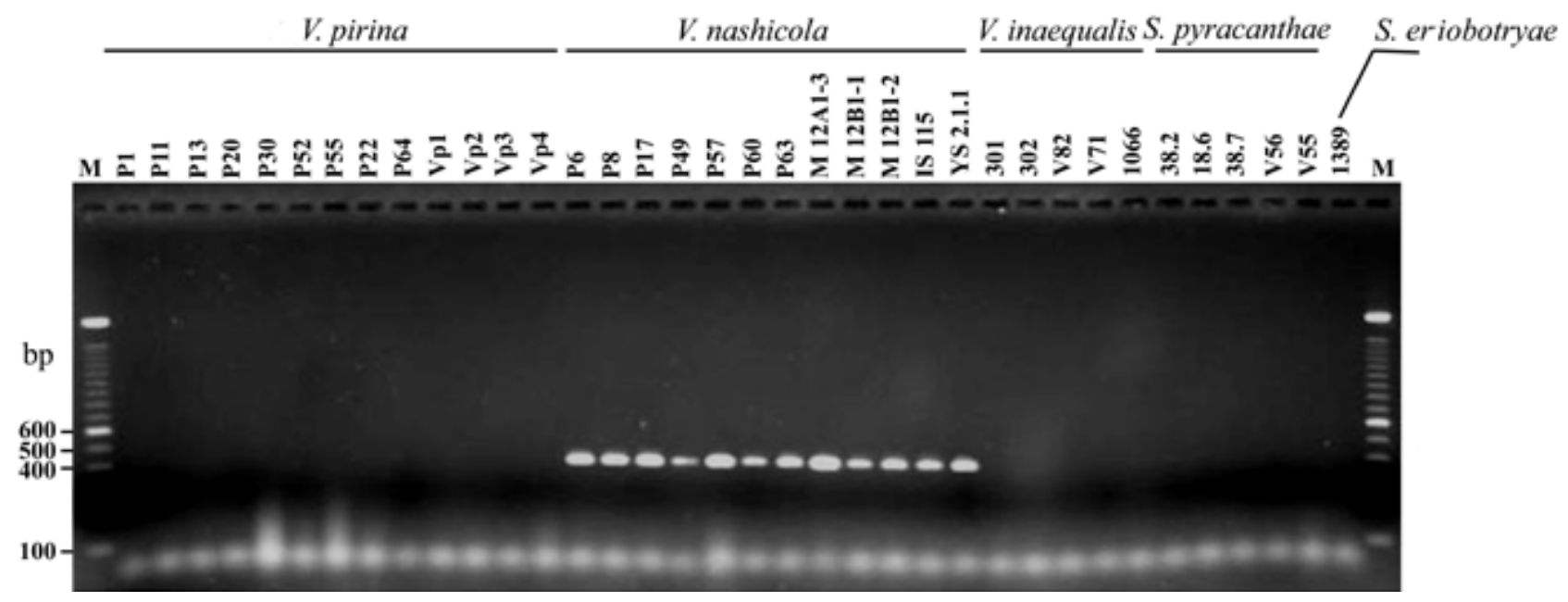

Fig. 3. Polymerase chain reaction amplifications of Venturia nashicola strains (P6 to Y 2.1.1) with specific primers set (A126, 5'-ACCCTGCCTGGAAAATC3'; internal transcribed spacer 4 [ITS4], 5'-TCCTCCGCTTATTGATATGC-3') provided an expected DNA fragment of 391 bp. This primer set does not allow any amplification with DNA from V. pirina or with other Venturia and Spilocaea pathogens. Lane M, 100-bp ladder. 
regardless of the geographic origin (Japan and France). The specificity of these primers was checked by the absence of cross reactivity with DNA from different species of Venturia isolated from European pear and Malus $\times$ domestica, which is genetically close to $V$. nashicola (14), and also from species less close to Pyrus such as Pyracantha and Eriobotrya japonica.

We also showed in this study that of the 10 DNA sequences aligned, the size of ITS region from $V$. pirina was always longer by one or two bases than that of $V$. nashicola. This characteristic and the existence of mismatches between the two species could be visualized by single-strand conformation polymorphism studies (SSCP). Kumeda and Asao (12) differentiated species of Aspergillus section Flavi using this technique on the ITS region that differed in a range of only 20 bases. SSCP is a powerful tool, nevertheless, it appears much more difficult to develop for a strategy of routine detection than a molecular identification with species-specific primers.

The proposed PCR identification protocol is rapid, and the results are unambiguous in regard to what is particularly useful to countries where $V$. nashicola is a quarantine pathogen. However, a step of fungal culture remains necessary. In order to use these specific primers in the detection of this organism, further development is needed to detect the fungus from infected host. Protocols for direct DNA extraction from leaves are established for many fungi including $V$. inaequalis (11). They must be optimized to set up a procedure in a certification scheme for Pyrus.

\section{ACKNOWLEDGMENTS}

We thank H. Ishii, A. Kollar, and J. L. Notteghem for providing fungal strains and J. Gaudin for helpful technical assistance.

\section{LITERATURE CITED}

1. Desmarais, E., Lanneluc, I., and Lagnel, J. 1998. Direct amplification of length polymorphisms (DALP), or how to get and characterize new genetic markers in many species. Nucleic Acids Res. 26:1458-1465.

2. Edel, V., Steinberg, C., Gautheron, N., and Alabouvette, C. 2000. Ribosomal DNA-targeted oligonucleotides probe and PCR specific for Fusarium oxysporum. Mycol. Res. 104:518-526.

3. Freeman, S., Minz, D., Jurkevitch, E., Maymon, M., and Shabi, E. 2000. Molecular analyses of Colletotrichum species from almond and other fruits. Phytopathology 90:608-614.

4. Goodwin, D. C., and Lee, S. B. 1993. Microwave miniprep of total genomic DNA from fungi, plants, protists and animals for PCR. Biotechniques 15:438-444.

5. Hamelin, R. C., Bourassa, M., Rail, J., Dusabenyagasani, M., Jacobi, V., and Laflamme, G. 2000. PCR detection of Gremmeniella abietina, the causal agent of scleroderis canker of pine. Mycol. Res. 104:527-532.

6. Iketani, H., Manabe, T., Matsuta, N., Akihama, T., and Hayashi, T. 1998. Incongruence between RFLPs of chloroplast DNA and morphological classification in east Asian pear (Pyrus spp.). Genet. Resour. Crop Evol. 45:533-539.
7. Ishii, H., and Suzaki, H. 1994. Isozyme variation and inheritance of Venturia species causing scab on pears. Norw. J. Agric. Sci. Suppl. 17:113-122.

8. Ishii, H., Udagawa, H., Nishimoto, S., Tsuda, T., and Nakashima, H. 1992. Scab resistance in Pear species and cultivars. Acta Phytopathol. Entomol. Hung. 27:293-298.

9. Ishii, H., Watanabe, H., and Tanabe, K. 1997. Physiological races of Venturia nashicola on pears. Pages 130-133 in: Integrated Control of Pome Fruit Diseases. Vol. 9. A. M. Berrie, X. M. Xu, D. C. Harris, A. L. Roberts, K. Evans, D. J. Barbara, and C. Gessler, eds. IOBC/WPRS, Gent, Belgium.

10. Ishii, H., and Yanase, H. 2000. Venturia nashicola, the scab fungus of Japanese and Chinese pears: A species distinct from V. pirina. Mycol. Res. 104:755-759.

11. Koller, B., Tenzer, I., and Gessler, C. 2001. SSR analysis of apple scab lesions. Pages 93-98 in: Integrated Control of Pome Fruit Diseases. Vol. 12. L. Parisi, ed. IOBC/WPRS, Gent, Belgium.

12. Kumeda, Y., and Asao, T. 1996. Single-strand conformation polymorphism analysis of PCR-amplified ribosomal DNA internal transcribed spacers to differentiate species of Aspergillus section Flavi. Appl. Environ. Microbiol. 62:2947-2952.

13. Roberts, A. L., and Crute, I. R. 1994. Apple scab resistance from Malus floribunda $821(\mathrm{Vf})$ is rendered ineffective by isolates of Venturia inaequalis from Malus floribunda. Norw. J. Agric. Sci. Suppl. 17:403406.

14. Schnabel, G., Schnabel, E. L., and Jones, A. L. 1999. Characterization of ribosomal DNA from Venturia inaequalis and its phylogenetic relationship to rDNA from other tree-fruit Venturia species. Phytopathology 89:100-108.

15. Shabi, E., Rotem, J., and Loebenstein, G. 1973. Physiological races of Venturia pirina on pear. Phytopathology 63:41-43.

16. Sherriff, C., Whelan, M. J., Arnold, G. M., Lafay, J.-F., Brygoo, Y., and Bailey, J. A. 1994. Ribosomal DNA sequence analysis reveals new species groupings in the genus Colletotrichum. Exp. Mycol. 18:121-138.

17. Sivanesan, A. 1977. The Taxonomy and Pathology of Venturia Species. J. Cramer, Vaduz, Liechenstein.

18. Stanton, W. R. 1953. Breeding pears for resistance of the pear scab fungus Venturia pirina Aderh. I. Variation in the pathogenicity of Venturia pirina. Ann. Appl. Biol. 40:184-191.

19. Tanaka, S., and Yamamoto, S. 1964. Studies on pear scab. II. Taxonomy of the causal fungus of Japanese pear scab. Ann. Phytopathol. Soc. Jpn. 29:128-136.

20. Vos, P., Hogers, R., Bleeker, M., Reijans, M., van de Lee, T., Hornes, M., Frijters, A., Pot, J., Peleman, J., Kuiper, M., and Zabeau, M. 1995. AFLP: A new technique for DNA fingerprinting. Nucleic Acids Res. 23:4407-4414

21. Wang, P. H., and White, J. G. 1997. Molecular characterization of Pythium based on RFLP analysis of the internal transcribed spacer region of ribosomal DNA. Physiol. Mol. Plant. Pathol. 51:129-143.

22. Welsh, J., and McClelland, M. 1990. Fingerprinting genomes using PCR with arbitrary primers. Nucleic Acids Res. 18:7213-7218.

23. White, T. J., Bruns, T., Lee, S., and Taylor, J. 1990. Amplification and direct sequencing of fungal ribosomal RNA genes for phylogenetics. Pages 315-322 in: PCR Protocols, A Guide to Methods and Applications. M. A. Innis, D. H. Gelfand, J. J. Sninsky, and T. J. White, eds. Academic Press, San Diego, CA.

24. Williams, J. G. K., Kubelik, A. R., Livak, K. J., Rafalski, J. A., and Tingey, S. V. 1990. DNA polymorphism amplified by arbitrary primers are useful as genetic markers. Nucleic Acids Res. 8:6531-6535. 